\title{
Assessment of shear bond strength of brackets bonded by direct and indirect techniques: An in vitro study
}

Roberto Hideo Shimizu', Karlos Giovani Grando², Isabela Almeida Shimizu³, Augusto Ricardo Andriguetto ${ }^{3}$, Ana Cláudia Moreira Melo ${ }^{3}$, Eduardo Leão Witters²

Objective: This in vitro study was designed to evaluate the shear bond strength (SBS) of orthodontic metal brackets bonded by direct and indirect techniques.

Methods: Thirty healthy human maxillary premolar teeth were used. The teeth were divided into three groups of 10 teeth each: Group I - indirect bonding with Sondhi ${ }^{\top M}$ Rapid-Set system (3M/Unitek), Group II - indirect bonding with Transbond ${ }^{\mathrm{TM}} \mathrm{XT}$ adhesive system (3M/Unitek) and Group III - direct bonding with Transbond ${ }^{\text {TM }}$ XT adhesive system (3M/Unitek). After bonding and obtaining the specimens for the study, the specimens were subjected to SBS testing in a universal testing machine (Emic, model DL-500). The Kolmogorov-Smirnov test was applied to ascertain that the data had a normal distribution and the Bartlett test to check whether there was homogeneity of variance. One-factor analysis of variance was performed and, subsequently, Tukey's test for paired means. A 5\% significance level was adopted.

Results: The results of Group I were 67.6 (N) and 5.9 (MPa); Group II, 68.9 (N) and 6.1 (MPa) and Group III (control), $92.5(\mathrm{~N})$ and $8.1(\mathrm{MPa})$.

Conclusion: It can therefore be concluded that the means for Group III were significantly higher compared with Groups I and II in both Newton (N) and Megapascal (MPa) values. The means attained by the indirect bonding technique used in Groups I and II, however, exhibited no statistically significant differences.

Keywords: Dental bonding. Dental debonding. Shear bond strength. Corrective orthodontics.

${ }^{1}$ Associate Professor of Orthodontics, UTR. Professor of Post-graduation course, UTP, ILAPEO and ABO.

${ }^{2}$ Specialist in Orthodontics, Tuiuti University.

${ }^{3}$ Professor of Post-graduation course, UTP, ILAPEO and ABO.
How to cite this article: Shimizu RH, Grando KG, Shimizu IA, Andriguetto AR, Melo ACM, Witters EL. Assessment of shear bond strength of brackets bonded by direct and indirect techniques: An in vitro study. Dental Press J Orthod. 2012 July-Aug;17(4):23.el-7.

Submitted: November 16, 2009 - Revised and accepted: June 20, 2011

» The authors report no commercial, proprietary or financial interest in the products or companies described in this article.

Contact address: Roberto Hideo Shimizu

Rua Padre Anchieta, 1846 - Bigorrilho - Curitiba/PR, Brazil

Zip code: 80.730-000 - E-mail: robertoshimizu@yahoo.com.br 


\section{Avaliação da resistência ao cisalhamento de braquetes colados pelas técnicas direta e indireta: estudo in vitro}

Roberto Hideo Shimizu', Karlos Giovani Grando², Isabela Almeida Shimizu³, Augusto Ricardo Andriguetto ${ }^{3}$, Ana Cláudia Moreira Melo ${ }^{3}$, Eduardo Leão Witters²

Objetivo: objetivou-se com esse trabalho avaliar, em um estudo realizado in vitro, a resistência ao cisalhamento de braquetes metálicos ortodônticos colados pelas técnicas direta e indireta.

Métodos: foram utilizados 30 dentes pré-molares superiores humanos hígidos. Os dentes foram divididos em três grupos de 10 dentes: Grupo I - colagem indireta com sistema Sondhi Rapid-Set (3M/Unitek); Grupo II - colagem indireta com sistema Transbond XT (3M/Unitek); e Grupo III - colagem direta com sistema Transbond XT (3M/Unitek). Após realização das colagens e confecção dos corpos de prova, esses foram submetidos ao teste de cisalhamento em uma máquina universal de ensaios da marca comercial EMIC, modelo DL-500. Foram aplicados os testes de Kolmogorov-Smirnov, para verificar se os dados tinham uma distribuição normal, e o teste de Bartlett, para verificar se existia igualdade entre as variâncias. Aplicou-se a análise de variância de um fator e, posteriormente, o teste de Tukey para o contraste pareado de médias. O nível de significância foi de 5\%.

Resultados: os resultados do Grupo I foram 67,6N e 5,9MPa; do Grupo II foram 68,9N e 6,1MPa; e do Grupo III (controle), 92,5N e 8,1MPa.

Conclusão: pode-se concluir que tanto para os valores em Newtons (N) como para os valores em Megapascal (MPa), a média do Grupo III foi significativamente maior em relação aos Grupos I e II. Já para as médias onde a técnica indireta foi usada (Grupos I e II), não houve diferenças estatisticamente significativas.

Palavras-chave: Colagem dentária. Descolagem dentária. Resistência ao cisalhamento. Ortodontia corretiva.

${ }^{1}$ Professor Adjunto Doutor da Disciplina de Ortodontia da UTP-PR. Professor da Pós-graduação da UTP-PR, ILAPEO e ABO.

${ }^{2}$ Especialista em Ortodontia pela Universidade Tuiuti do Paraná.

${ }^{3}$ Professor da Pós-graduação da UTP-PR, ILAPEO e ABO.
Como citar este artigo: Shimizu RH, Grando KG, Shimizu IA, Andriguetto AR, Melo ACM, Witters EL. Assessment of shear bond strength of brackets bonded by direct and indirect techniques: An in vitro study. Dental Press J Orthod. 2012 July-Aug;17(4):23.el-7.

Enviado em: 16 de novembro de 2009 - Revisado e aceito: 20 de junho de 2011

» Os autores declaram não ter interesses associativos, comerciais, de propriedade ou financeiros que representem conflito de interesse nos produtos e companhias descritos nesse artigo.

Endereço para correspondência: Roberto Hideo Shimizu Rua Padre Anchieta, 1846 - Bigorrilho - Curitiba/PR - CEP: 80.730-000 E-mail: robertoshimizu@yahoo.com.br 


\section{INTRODUCTION}

Orthodontics, as a dental specialty, depends on quality adhesive systems to ensure effective orthodontic treatment. That's why selecting a suitable bracket bonding technique becomes vital to success.

The bonding procedure, although temporary, should be robust enough to withstand orthodontic forces and the loads resulting from occlusion. ${ }^{23}$ Currently the best clinical results are achieved by those orthodontists who more properly place their brackets. ${ }^{20}$ Thus, bracket bonding to the enamel surface of teeth is a clinical procedure that can be performed either directly, by positioning the bracket on the tooth surface directly, or indirectly-a technique that consists of two steps, one in the lab and one at the clinical setting. In the first step, the brackets are positioned on the model and transfer trays are fabricated; in the second, the brackets are positioned on the teeth with the aid of these trays. ${ }^{15}$

The following are some of the benefits of indirect bonding: Greater precision in bonding the brackets; less time spent repositioning accessories, which saves in-office time; simultaneous bonding of all brackets, which translates into reduced chair time; reduced patient discomfort and fewer bond failures. ${ }^{16}$ In contrast, this technique also suffers from some disadvantages, such as laboratory work time, higher cost, greater number of stages, and the interface between the bonding adhesive and the primer applied to the tooth, which may impair adhesion.

Indirect bonding facilitates correct positioning of brackets as it provides a view of the teeth on the model in all planes of space, providing improved vertical positioning of brackets. It has also proven more accurate in terms of angulation. ${ }^{5}$ Thus, the aim of the present study was to evaluate, by means of mechanical testing, the shear bond strength (SBS) of brackets bonded by direct and indirect techniques.

\section{MATERIAL AND METHODS}

Thirty human upper premolar teeth were extracted for orthodontic purposes. These teeth exhibited intact buccal surfaces, no cracks or fractures from the extraction, and absence of caries or demineralization.
The teeth were divided into three groups of 10 teeth each $(n=10)$ :

» Group I: Indirect bonding using Sondhi ${ }^{\mathrm{TM}}$ Rapid-Set system (3M/Unitek).

» Group II: Indirect bonding using Transbond ${ }^{\mathrm{TM}}$ XT adhesive system (3M/Unitek).

» Group III: Direct bonding using Transbond $\mathrm{XT}^{\mathrm{TM}}$ adhesive system (3M/Unitek).

The method used in this investigation was previously tested ${ }^{15,16}$ by fixing the teeth by their roots in cast-stone type IV (Durone ${ }^{\mathrm{TM}}$ ) on a metal plate (die-casting), keeping the crowns exposed. After taking an impression with alginate(Jeltrat) and pouringspecial plaster type IV(Durone), a model was obtained for indirect bonding of Groups I and II. Group III (control) was kept in artificial saliva up to the moment that direct bonding was performed.

Clinical crown size was determined and the plaster models marked with pencil to define the buccal axis of the clinical crown. Gemini brackets (3M/Unitek), MBT prescription, 0.022-in slot, were bonded to the anatomical crowns using a thin layer of Transbond $^{\mathrm{TM}}$ XT (3M Unitek) light cured adhesive, taking into account the buccal axis of the clinical crown (BACC). After removing the excess of adhesive with a probe, each bracket was light cured for 25 seconds using a Radii-Call-SDI LED light curing unit.

After bonding the brackets on the model, individual trays were fabricated in a vacuum machine (VH) using a sheet of 1-mm flexible silicone vinyl overlaid with a sheet of rigid crystal PVC with 1-mm thickness. A tray fabricated for the plaster model, was cut and divided into four segments with the aid of scissors and a carborundum disk, and removed from the model along with the brackets and the resin on their bases.

After prophylaxis with pumice (SS White) mixed with water and a Robinson brush (Microdent ${ }^{\mathrm{TM}}$ ) at low speed (Kavo) for 10 seconds each, the teeth were washed and dried for the same time length and etched with phosphoric acid at $37 \%$ (Maquira) for 20 seconds, then washed for the same time length. They were then dried again with sprays of oil-free compressed air for 10 seconds. A similar procedure was performed in the three groups.

A portion of the natural teeth in Group I received a layer of Sondhi ${ }^{\mathrm{TM}}$ Rapid-Set (3M/Unitek) resin A, while the resin on the bracket bases received a layer of Sondhi ${ }^{\mathrm{TM}}$ resin B. Thereafter, the first segment of the tray was adapted and pressed for 30 seconds onto the 
natural teeth for 2 more minutes ${ }^{16}$ according to manufacturer's instructions. Next, the two tray blades were removed with the aid of an explorer probe, while the brackets remained attached to the natural teeth, attached to the plaster. The same procedures were performed for each tray segment until all the teeth had received some indirect bonding resin.

In Group II, a layer of Transbond ${ }^{\mathrm{TM}} \mathrm{XT}$ adhesive system primer (3M/Unitek) was applied to the teeth and another layer of the same primer was applied to the resin on the bases of the bracket in the same group. The first tray segment was adapted and each tooth was light cured for 25 seconds (LED Radii Call -SDI). Next, the tray blades were also removed in the same manner as in Group I, until all the teeth had received indirect bonding adhesive. Again, the brackets were light cured for another 25 seconds each.

In Group III, direct bonding was performed using Transbond $^{\mathrm{TM}}$ XT (3M Unitek) primer and adhesive.

The teeth with brackets bonded to them were removed from the plaster bases and placed on PVC pipe $\left(\right.$ Tigre $^{\mathrm{TM}}$ ) segments with $15 \mathrm{~mm}$ diameter and 22 $\mathrm{mm}$ height containing self-cured acrylic resin (JET, handled according to manufacturer's directions) assisted by a guide for standardization of test specimens (GSTS), as shown in Figure 1.

Once the bracket was bonded to the tooth, an elastic modulus was attached to the GSTS orthodontic wire. Then, the PVC pipes were filled with colorless acrylic resin $\left(\mathrm{JET}^{\mathrm{TM}}\right)$ as far as the upper edge.

The samples were then subjected to SBS tests in a universal testing machine (EMIC ${ }^{\mathrm{TM}}$, model DL-500, with a speed of $0.5 \mathrm{~mm} / \mathrm{min}$ with $1 \mathrm{kN}$ (100 kgf) capacity, reading resolution of $0.1 \mathrm{~N}$ (10 gf), using recommended parameters for testing within a range between 20 and $1000 \mathrm{~N}$. The chisel type working tip (developed for this purpose by ODEME Company) was positioned in the occlusogingival direction in contact with the bracket, between the tie-wing and the base, close to the base (Fig 2). The breaking loads were measured in Newtons (N).

Data were tabulated in Newton $(\mathrm{N})$ and $\mathrm{MPa}$ (Megapascal) in order to obtain mean values for the force $(\mathrm{N})$ and stress generated $(\mathrm{MPa})$, and compare these with the literature. The data in Newton (N) and Megapascal (MPa) were previously tested for normality and homoscedasticity, which are the basic prerequisites used in analysis of variance. The tests used were: Kolmogorov-Smirnov test to verify that the data had a normal distribution, and the Bartlett test to check whether there was homogeneity of variance.

If the data exhibited a pattern of normality and homogeneity of variance, i.e., if they were parametric, a one-factor analysis of variance would be applied. The factor analyzed was Material, with $3 \mathrm{lev}$ els. Should differences occur, Tukey's test for paired contrast of means would be applied. A 5\% significance level was adopted. If one of the normality parameters of data was violated, a nonparametric analysis would be applied and the Kruskal-Wallis test would be applied to verify the overall difference between groups, as well as the Mann-Whitney test for paired comparison. In this case, the same significance level of $5 \%$ was also adopted.

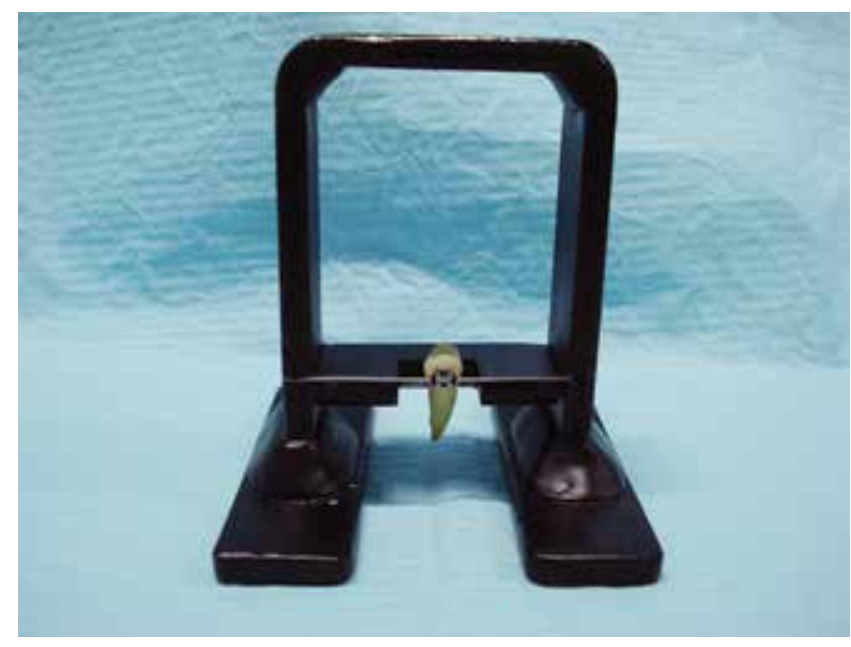

Figure 1 - Guide for standardization of test specimens (GSTS).

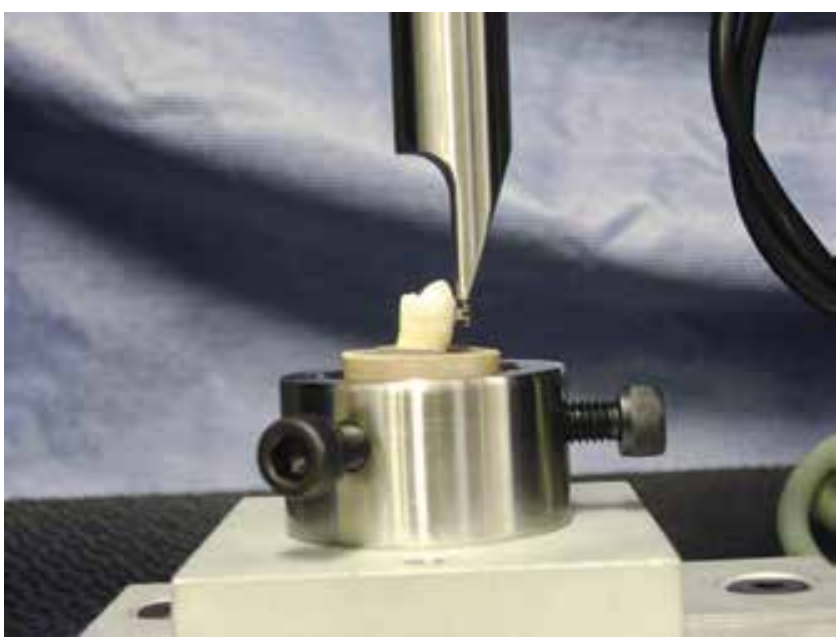

Figure 2 - Test system ready for shear bond test. 


\section{RESULTS}

\section{Exploratory analysis}

Individual force $(\mathrm{N})$ and stress $(\mathrm{MPa})$ results are presented in Table 1 and Figures 3 and 4.

Figures 3 and 4 show a graphical presentation of the same data depicted in Table 1.

Table 2 shows the mean values and standard deviations in $\mathrm{N}$ and $\mathrm{MPa}$ for each of the techniques tested.

It is clear that the mean values ( $\mathrm{MPa}$ or $\mathrm{N}$ ) for the direct technique used as control showed higher values than the indirect techniques, either with Sondhi ${ }^{\mathrm{TM}}$ Rapid-Set or Transbond ${ }^{\mathrm{TM}}$ XT system.

This increase in values for the direct technique was around 26 to $27 \%$ when compared with the indi- rect technique, Transbond ${ }^{\mathrm{TM}} \mathrm{XT}$ and Sondhi ${ }^{\mathrm{TM}}$ RapidSet systems. In the case of indirect techniques, these mean values were very similar.

The same data presented in Table 2 are arranged graphically in Figures 5 and 6.

\section{Inferential analysis}

Given the fact that the mean data in $\mathrm{N}$ and $\mathrm{MPa}$ showed in Table 2 remained within a standard of normality and homogeneity of variance, one-factor analysis of variance was applied. This analysis was statistically significant $(\mathrm{p}<0.05)$. Thus, Tukey's test was applied for contrast between paired means. The result can be seen in Table 3 .

Table 1 - Individual values in Newton $(N)$ showing force exerted between bracket and enamel when bonded using three different techniques.

\begin{tabular}{|c|c|c|c|c|c|c|}
\hline \multirow[b]{2}{*}{ Techniques } & \multicolumn{3}{|c|}{ Values in Newton } & \multicolumn{3}{|c|}{ Values in Megapascal } \\
\hline & $\begin{array}{c}\text { Control } \\
\text { (direct technique) }\end{array}$ & $\begin{array}{c}\text { Sondhi }{ }^{\mathrm{TM}} \\
\text { Rapid-Set system }\end{array}$ & $\begin{array}{c}\text { Transbond XT } \\
\text { adhesive system }\end{array}$ & $\begin{array}{c}\text { Control } \\
\text { (direct technique) }\end{array}$ & $\begin{array}{c}\text { Sondhi }^{\mathrm{TM}} \\
\text { Rapid-Set system }\end{array}$ & $\begin{array}{l}\text { Transbond XT } \\
\text { adhesive system }\end{array}$ \\
\hline & 80.4 & 71.4 & 80.2 & 7.0 & 6.3 & 7.1 \\
\hline & 72.6 & 44.1 & 41.4 & 6.4 & 3.9 & 3.6 \\
\hline & 119.8 & 44.9 & 103.1 & 9.9 & 4.3 & 3.4 \\
\hline & 72.5 & 107.2 & 107.1 & 6.3 & 9.4 & 9.4 \\
\hline & 88.8 & 41.8 & 31.5 & 7.8 & 3.7 & 2.8 \\
\hline & 67.7 & 62.9 & 110.2 & 5.9 & 5.5 & 9.7 \\
\hline & 86.2 & 86.9 & 50.9 & 7.5 & 7.7 & 4.5 \\
\hline & 114.6 & 58.3 & 70.2 & 10.2 & 5.1 & 6.2 \\
\hline & 115.2 & 109.5 & 55.7 & 10.1 & 9.6 & 4.9 \\
\hline
\end{tabular}

Source: Research data.

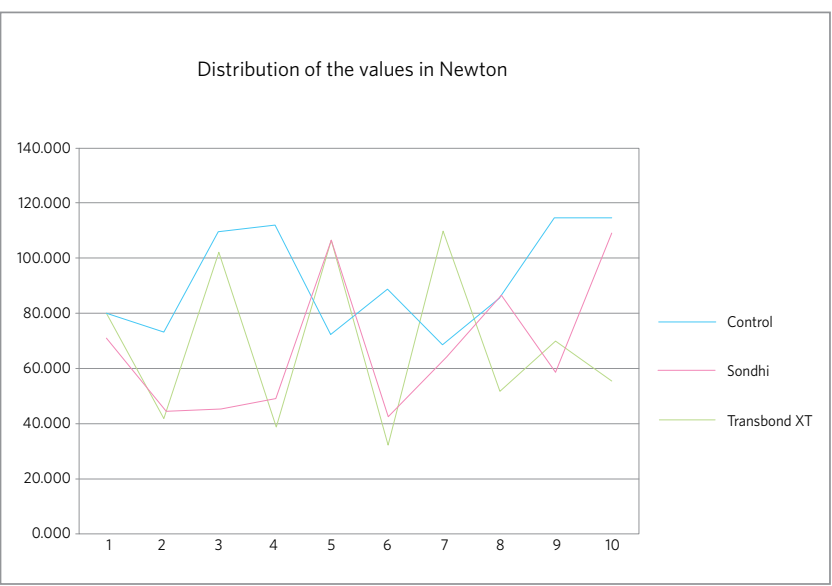

Figure 3 - Individual values in Newton $(N)$ showing force exerted between bracket and enamel when bonding performed using three different techniques.

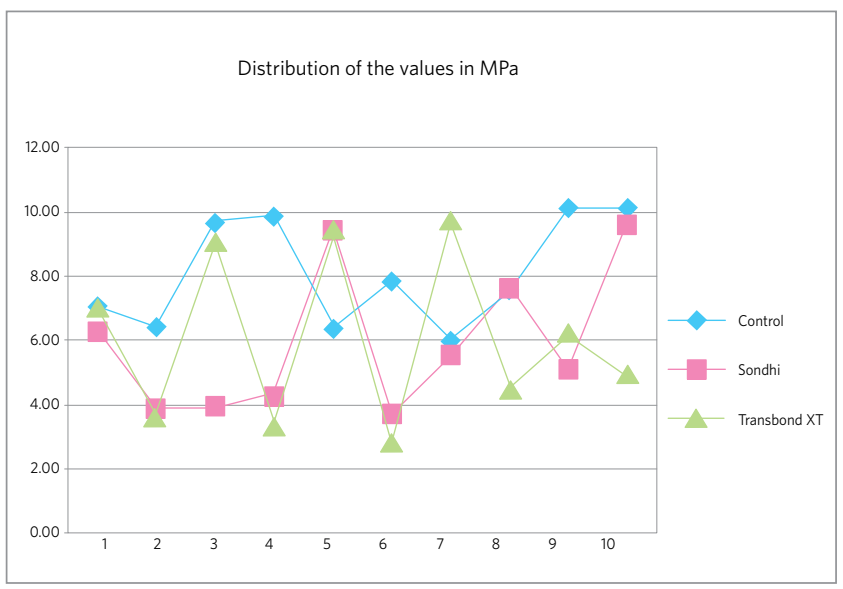

Figure 4 - Individual values in Megapascal (MPa) showing force exerted between bracket and enamel when bonding performed using three different techniques. 
It is evident that for both values, i.e., Newton and Megapascal, the mean value for the control group (direct technique) was significantly higher than in the groups where the indirect technique was used, either with the Sondhi ${ }^{\mathrm{TM}}$ Rapid-Set system or Transbond $^{\mathrm{TM}}$ XT system $(\mathrm{p}<0.05$, Table 3$)$. Moreover, the means found where the indirect technique was used (Sondhi ${ }^{\mathrm{TM}}$ Rapid-Set system and Transbond ${ }^{\mathrm{TM}}$ XT system), both in Newton and in Megapascal, showed no statistically significant differences $(\mathrm{p}<0.05)$.

\section{DISCUSSION}

The literature is controversial when it comes to assessing direct and indirect bracket bonding techniques. There are authors who claim direct bonding is the most efficient ${ }^{11,19}$ while others advocate indirect bonding, either because of the benefits or in the light of the results achieved over the years., ${ }^{4,10,14,15}$ Others believe that both yield similar results and therefore can be used in orthodontic practice without major concerns. ${ }^{1,2,8,22}$ Direct bonding has the following advantages: It leaves a smaller space between bracket base and enamel surface, resin removal can be conveniently performed after bracket debonding, the bracket base is wholly filled with adhesive, ${ }^{23}$ it does not comprise a laboratory phase, and the entire bonding procedure takes less time, ${ }^{1,16}$ besides its lower cost. On the other hand, indirect bonding is straightly associated with: Simultaneous bonding of all brackets, comfort for professionals and patients, ${ }^{4,15,16}$ increased

Table 2 - Means and standard deviations (SD) of force in Newtons (N) and stress (MPa) showing force exerted between bracket and enamel when bonding performed using three different techniques.

\begin{tabular}{|c|c|c|c|c|c|c|}
\hline & Values in Newton & & & Values in Megapa & & \\
\hline Techniques & $\begin{array}{l}\text { Control } \\
\text { (direct technique) }\end{array}$ & $\begin{array}{l}\text { Sondhi }{ }^{\mathrm{TM}} \\
\text { Rapid-Set system }\end{array}$ & $\begin{array}{l}\text { Transbond } X T^{\mathrm{TM}} \\
\text { adhesive system }\end{array}$ & $\begin{array}{l}\text { Control } \\
\text { (direct technique) }\end{array}$ & $\begin{array}{l}\text { Sondhi }{ }^{\mathrm{TM}} \\
\text { Rapid-Set system }^{\text {Ret }}\end{array}$ & $\begin{array}{l}\text { Transbond XT } \\
\text { adhesive system }\end{array}$ \\
\hline Mean $\pm S D$ & $92.5 \pm 19.2$ & $67.6 \pm 25.6$ & $68.9 \pm 29.9$ & $8.1 \pm 1.7$ & $5.9 \pm 2.3$ & $6.1 \pm 2.6$ \\
\hline
\end{tabular}

Source: Research data.

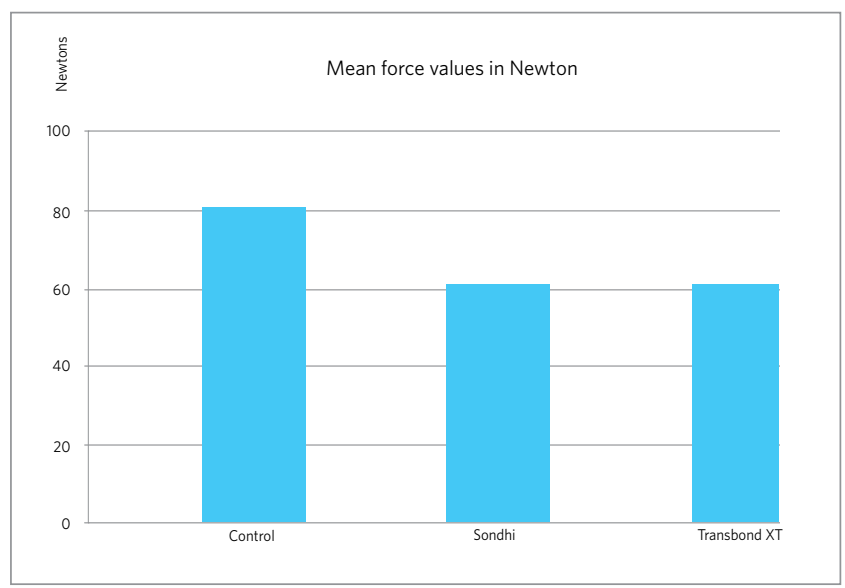

Figure 5 - Mean force values in Newton $(N)$ showing force exerted between bracket and enamel when bonding performed using three different techniques.

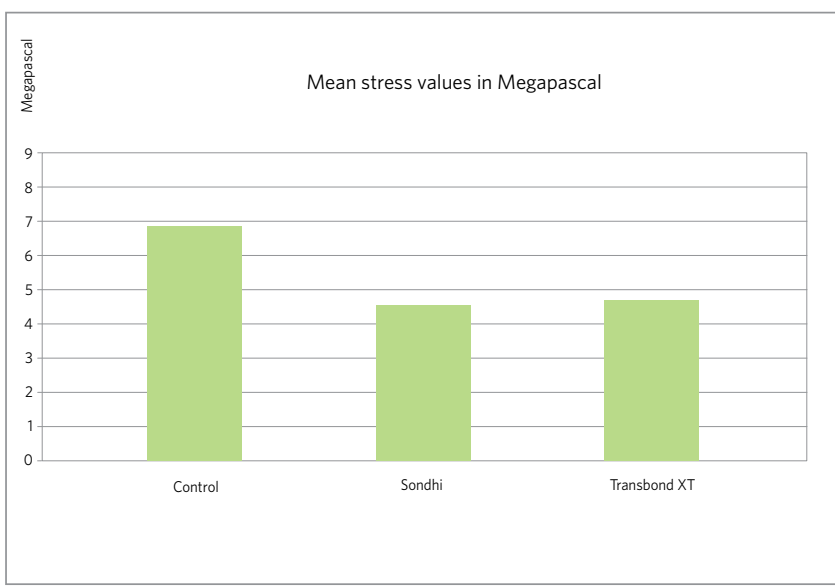

Figure 6 - Mean stress values in Megapascal, showing force exerted between bracket and enamel when bonding performed using three different techniques.

Table 3 - Means and standard deviations (SD), and results of Tukey's test, force in Newton (N) and stress (MPa) showing force exerted between bracket and enamel when bonding performed using three different techniques.

\begin{tabular}{ccccccc} 
& Values in Newton & & \multicolumn{2}{c|}{ Values in Megapascal } \\
Techniques & $\begin{array}{c}\text { Control } \\
\text { (direct technique) }\end{array}$ & $\begin{array}{c}\text { Sondhi }{ }^{\mathrm{TM}} \\
\text { Rapid-Set system }\end{array}$ & $\begin{array}{c}\text { Transbond XT } \\
\text { adhesive system }\end{array}$ & $\begin{array}{c}\text { Control } \\
\text { (direct technique) }\end{array}$ & $\begin{array}{c}\text { Sondhi }^{\mathrm{TM}} \\
\text { Rapid-Set system }\end{array}$ & $\begin{array}{c}\text { Transbond XT } \\
\text { adhesive system }\end{array}$ \\
Mean \pm SD & $92.5 \pm 19.2^{\mathrm{A}}$ & $67.6 \pm 25.6^{\mathrm{B}}$ & $68.9 \pm 29.9^{\mathrm{B}}$ & $8.1 \pm 1.7^{\mathrm{a}}$ & $5.9 \pm 2.3^{\mathrm{b}}$ & $6.1 \pm 2.6^{\mathrm{b}}$ \\
\hline
\end{tabular}

${ }^{\star}$ ) Different uppercase or lowercase letters indicate statistical significance $(p<0.05)$. 
accuracy in bracket positioning ${ }^{2,14,15}$ as there is no interference from external factors such as saliva, cheeks and tongue. Finally, guidelines can be drawn onto the teeth in the working model, providing references for the correct placement of the orthodontic accessories.

Studies conducted in the field of orthodontics have made use of several types of mechanical tests. Among these are: Shear bond strength and tensile strength. Shear bond strength testing is the most widely used because it simulates, to a certain extent, what happens clinically. ${ }^{5}$ This was one of the reasons why the authors chose to utilize this type of test.

It is noteworthy that performing shear stress on systems used for bonding orthodontic accessories depends on the parallelism between the force line of action and the bonding surface. In the shear test, the force is directed parallel to the long axis of the teeth and as close as possible to the bracket-tooth interface. ${ }^{5}$ In order to achieve this parallelism, a bracket position indicator was developed where the specimens could be consistently assembled to ensure reliable results.

The technique and bonding material used by orthodontists should promote sufficient adhesion between the brackets and teeth as to withstand the application of forces during treatment. Transbond ${ }^{\mathrm{TM}} \mathrm{XT}$ was chosen as control in this study as it yields good clinical outcomes and is widely used by researchers. ${ }^{3,4,5,7,8,18,19,21,22}$ Studies were conducted in order to evaluate the effect of self-etching, hydrophobic and hydrophilic primers. ${ }^{6,7,13,17}$

The use of Transbond ${ }^{\mathrm{TM}} \mathrm{XT}$ adhesive system in this investigation proved efficient once the values for shear bond strength for the control group were higher than those advocated in the literature. ${ }^{12}$ This adhesive system showed high shear bond strength when used with five different brands of metal brackets, both in terms of maximum strength (MPa) and breaking strength values. ${ }^{21}$

In this study, a statistically significant difference was found between the group employing direct bonding with Transbond ${ }^{\mathrm{TM}}$ XT (Group III, control) and the two other groups, which used indirect bonding (Group I - Sondhi ${ }^{\mathrm{TM}}$ Rapid-Set system and Group II - Transbond ${ }^{\mathrm{TM}}$ XT system) in both Newton and Megapascal values. The increase in these values observed for Group III was around $26 \%$ to $27 \%$ when compared with the other groups.
In comparing the results yielded by Groups I and II only, no statistically significant difference was found. Although the literature demonstrates efficient SBS values for bondings of approximately $50 \mathrm{kgf}$ (4.9 $\mathrm{MPa})$, SBS values of 60 to $80 \mathrm{kgf}$ (5.88 to $7.84 \mathrm{MPa}$ ) should be obtained before bracket bonding is considered ideal. ${ }^{12}$ Since there were no statistical differences between Groups I and II, it seems logical to assert, based on the results of this study, that there is no need for a primer especially designed for indirect bonding since the primer provided with the conventional Transbond ${ }^{\mathrm{TM}} \mathrm{XT}$ adhesive system offered an SBS value that was similar to that observed with the Sondhi ${ }^{\mathrm{TM}}$ Rapid-Set system. These data are of particular importance for clinical orthodontists as they will not be hard pressed to spend money unnecessarily in order to achieve the same efficiency during the indirect bonding of brackets.

In assessing the shear bond strength of the Transbond $^{\mathrm{TM}} \mathrm{XT}$ system in a control group using bovine teeth and direct bonding, Sponchiado et $\mathrm{al}^{18}$ found a value of 9.29 $\mathrm{MPa}$, while another study found a value of $13.88 \mathrm{Mpa}^{9}$ These values were higher than the value found in this study, i.e., 8.1 MPa. When the shear bond strength of Sondhi ${ }^{\mathrm{TM}}$ Rapid-Set system was tested 24 hours after bonding, using bovine teeth, much higher values were found $(14.98 \text { and } 14.99 \mathrm{MPa})^{8,9}$ compared to this study (5.9 MPa), which used human teeth. In a similar study, higher values were found. ${ }^{22}$ The group using Sondhi ${ }^{\mathrm{TM}}$ Rapid-Set system (indirect bonding) yielded $10.9 \mathrm{MPa}$ and Transbond ${ }^{\mathrm{TM}} \mathrm{XT}$ (direct bonding), 11.2 $\mathrm{MPa}$, showing no statistically significant differences between them. Thus, all values were above those recommended by the literature ${ }^{1}$ (5.9 and 7.8 MPa) as suitable for use in clinical orthodontics.

When Transbond ${ }^{\mathrm{TM}} \mathrm{XT}$ was used in tensile tests using the direct bonding technique, it showed a higher value (12 MPa) than the one found in this study (8.1 MPa). ${ }^{19}$ However, when indirect bonding was employed, Transbond $^{\mathrm{TM}}$ exhibited a value of $8.49 \mathrm{MPa}$ and Sondhi ${ }^{\mathrm{TM}}$ Rapid-Set, 4.97 MPa, unlike the results of this research, which were 6.1 and $5.9 \mathrm{MPa}$, respectively. A value similar to this study (9.29 $\mathrm{MPa}$ ) was found in shear bond strength tests using the same material as control. ${ }^{18}$

Evidence shows that Sondhi ${ }^{\mathrm{TM}}$ Rapid-Set displays higher SBS values in the initial phase than Concise Enamel and Custon IQ, but after five minutes no sig- 
nificant differences could be found between them, ${ }^{15}$ unlike what happened in this research, in which Sondhi ${ }^{\mathrm{TM}}$ Rapid-Set presented the lowest values of shear strength after 12 hours of bonding.

Apparently, both direct and indirect bonding techniques can be considered satisfactory and similar to each other, ${ }^{1,2,23}$ once shear bond strength values were found to be above the minimum recommended by the literature for clinical use, which validates both bracket bonding techniques.

Long-term prospective clinical studies are needed to further establish the evidence-based efficiency of such materials. Professionals are advised to select their orthodontic bonding materials after a critical analysis of their composition, working properties and scientific foundations.

\section{CONCLUSIONS}

Based on the study outcomes and the statistical method applied it is reasonable to conclude that:

1) The means for Group III were significantly higher than those in Groups I and II in both Newton (N) and Megapascal (MPa) values.

2) There were no statistically significant differences between the means of Groups I and II, both in Newton (N) and in Megapascal (MPa) values.

3) The results found in the three groups were within the range of mean values found in the literature and can therefore be safely used in clinical orthodontic practice.

4) From a clinical standpoint, it is not necessary to use a primer specially designed for indirect bonding.

\section{REFERENCES}

1. Aguirre MJ, King GJ, Waldron JM. Assessment of placement and bond streng when comparing direct bonding to indirect bonding techniques. Am J Orthod. 1982 Oct;:82(4):269-76.

2. Battaglini RLS, Benvenga MN. Estudo comparativo entre as técnicas de colagem de "brackets" direta e indireta em ortodontia. Odontologia (USF). 1993 Jan-Dez;11(1):51-76.

3. Giannini C, Francisconi PAS. Resistência à remoção de braquetes ortodônticos sob ação de diferentes cargas contínuas. R Dental Press Ortodon Ortop Facial. 2008;13(3):42-9.

4. Guenthner TA, Larson BE. Indirect bonding: a technique for precision and effiency. Semin Orthod. 2007;13:58-63.

5. Ianni DF, Silva TBC, Simplicio AHM, Loffredo LCM, Ribeiro RP. Avaliação in vitro da força de adesão de materiais de colagem em ortodontia: ensaios mecânicos de cisalhamento. R Dental Press Ortodon Ortop Facial. 2004;9(1):39-48.

6. lijima M, Ito S, Muguruma T, Saito T, Mizoguchi I. Bracket bond strength comparison between new unfilled experimental self-etching primer adhesive and conventional filled adhesives. Angle Orthod. 2010 Nov;80(6):1095-9.

7. Joo HJ, Lee YK, Lee DY, Kim YJ, Lim YK. Influence of orthodontic adhesives and clean-up procedures on the stain susceptibility of enamel after debonding. Angle Orthod. 2011 Mar;81(2):334-40.

8. Klocke A, Shi J, Kahl-Nieke B, Bismayer U. Bond strength with custom base indirect bonding techniques. Angle Orthod. 2003 Apr;73(2):176-80. Erratum in Angle Orthod. 2003 Aug;73(4):485.

9. Klocke A, Shi J, Kahl-Nieke B, Bismayer U. In vitro evaluation of a moisture-active adhesive for indirect bonding. Angle Orthod. 2003 Dec;73(6):697-701.

10. Macedo A, Zanelato AT, Moresca R, Thurler RCSB. Colagem indireta em ortodontia. Ortodontia. 2008:41(2):148-53.

11. Pithon MM, Oliveira MV, Ruellas ACO. Estudo comparativo da resistência ao cisalhamento de braquetes metálicos colados com cimentos de ionômero de vidro reforçados com resina. Rev Saúde Com. 2006;2(1):127-34.

12. Reynolds IR. A review of direct orthodontic bonding. Br J Orthod. 1975; 2:171-8.
13. Santos BM, Pithon MM, Ruellas AC, Sant'Anna EF. Shear bond strength of brackets bonded with hydrophilic and hydrophobic bond systems under contamination. Angle Orthod. 2010 Sep;80(5):963-7.

14. Santos PCF, Monteiro ALV, Freitas BV, Irikita KLM, Santiago KM. Técnica da colagem indireta ortodôntica passo-a-passo. Orthod sci pract. 2008:1(2):200-17.

15. Sondhi A. Effective and efficient indirect bonding: The Sondhi method. Semin Orthod 2007;13: 43-57.

16. Sondhi A. Efficient and indirect bonding. Am J Orthod Dentofacial Orthop. 1999;115(4):352-9.

17. Soo PP, Green BM, Sondhi A. Effects of oxygen inhibition in indirect bonding with a hydrophilic adhesive. Am J Orthod Dentofacial Orthop. 2009 Feb;135(2):214-21.

18. Sponchiado AR, Wunderlich AE, Galleta OS, Rosa M. Avaliação do uso do Self Atching Primer na 'colagem de braquetes ortodônticos metálicos. R Dental Press Ortodon Ortop Facial. 2005;3(3):22-9.

19. Tortamano A, Nauff F, Naccarato SRF. Avaliação da força de tração em braquetes colados pela técnica indireta com diferentes sistemas de adesão. R Dental Press Ortodon Ortop Facial. 2007;12(3):104-10

20. Trevisi HJ, Zanelato RC, Zanelato ACT. Colagem indireta na técnica MBT. Rev Clín Ortodon Dental Press. 2002;1(2):47-59.

21. Vasques WO, Ciruffo PSD, Tirbell CAM, Miyamura ZY, Vedovello MF. Resistência ao cisalhamento de diferentes braquetes metálicos colados com resina composta fotoativada (Transbond). Estudo comparativo in vitro. RGO Rev Gaucha Odont. 2005;53(3):186-90.

22. Yi GK, Dunn WJ, Taloumis LJ. Shear bond strength comparison between direct and indirect bonded orthodontic brackets. Am J Orthod Dentofacial Orthop. 2003 Nov;124(5):577-81.

23. Zachrisson BU, Brobakken BO. Clinical comparison of direct bonding versus indirect bonding with a different bracket type and adhesives. Am J Orthod. 1978 Jul;74(1):62-78 